This is the accepted version of the following article:

Chocarro-Ruiz B., Fernández-Gavela A., Herranz S., Lechuga L. M. . Nanophotonic label-free biosensors for environmental monitoring. Current Opinion in Biotechnology, (2017). 45. : 175 - . 10.1016/j.copbio.2017.03.016,

which has been published in final form at https://dx.doi.org/10.1016/j.copbio.2017.03.016 () https://dx.doi.org/10.1016/j.copbio.2017.03.016. This manuscript version is made available under the CC-BY-NC-ND 4.0 license http://creativecommons.org/licenses/by-nc-nd/4.0/ 


\title{
Nanophotonic label-free biosensors for environmental monitoring
}

\author{
Blanca Chocarro-Ruiz ${ }^{\mathrm{a}}$, Adrián Fernández Gavela ${ }^{\mathrm{a}}$, Sonia Herranz ${ }^{\mathrm{a}}$ and Laura M. Lechuga ${ }^{{ }^{a}}$
}

aNanobiosensors and Bioanalytical Applications Group. Catalan Institute of Nanoscience and Nanotechnology (ICN2), CSIC, The Barcelona Institute of Science and Technology and CIBERBBN, Campus UAB, Ed-ICN2, 08193 Bellaterra, Barcelona, Spain.

* Corresponding author: laura.lechuga@icn2.cat

\begin{abstract}
The field of environmental monitoring has experienced a substantial progress in the last years but still the on-site control of contaminants is an elusive problem. In addition, the growing number of pollutant sources is accompanied by an increasing need of having efficient early warning systems. Several years ago biosensor devices emerged as promising environmental monitoring tools, but their level of miniaturization and their fully operation outside the laboratory prevented their use on-site. In the last period, nanophotonic biosensors based on evanescent sensing have emerged as an outstanding choice for portable point-of-care diagnosis thanks to their capability, among others, of miniaturization, multiplexing, label-free detection and integration in lab-on-chip platforms. This review covers the most relevant nanophotonic biosensors which have been proposed (including interferometric waveguides, grating-couplers, microcavity resonators, photonic crystals and localized surface plasmon resonance sensors) and their recent application for environmental surveillance.
\end{abstract}

\section{Highlights}

- We discuss the performance of different nanophotonic biosensors.

- We discuss the advantages that nanophotonic label-free biosensors confer over standard techniques.

- We present the most recent biosensing results for environmental monitoring.

\section{Introduction}

For decades environmental pollution, caused by heedless anthropogenic and industrial activities, has been a crucial concern and has been identified as the origin of the global climate change. Despite the concern at worldwide level and the investment in remediation actions, the slow but steady degradation of water, soil and air quality, continues. Real-time and on-site monitoring of the pollution is vital to managing environmental degradation and protecting their quality for the future of our world. In order to help in the prevention of the environmental degradation, there is an imperative need of innovative monitoring tools and early warning systems.

The conventional analytical techniques, based on chromatographic and spectroscopic technologies, remain the preferred analytical methods for environmental control due to its accuracy and sensitivity. But these methods are limited to centralised laboratories, require expensive instrumentation, are time consuming and need trained personnel. To overcome the high costs and low speed of those analysis, biosensor devices emerged as a promising 
alternative tool several years ago[1]. Biosensors can provide the demanded portable analytical tools and early warning systems because they are fast, specific, sensitive, reusable and enable permanent and unattended operation in the field [2].

A biosensor is a device that combines a biological or biomimetic recognition element with a transducer, to convert a specific (bio)chemical interaction into a measurable signal (see Fig. 1). A key component of the biosensor is the selected receptor that affects the specificity, response time, affinity, and lifetime of the biosensor [3]. The main biological receptors are antibodies (Abs) [4], DNA strands, aptamers or enzymes and the biomimetic ones, such as molecular imprinted polymers (MIPs). In addition, the way that the receptor was immobilized or conjugated on the transducer surface is a critical step for the efficient performance of the final biosensor device.

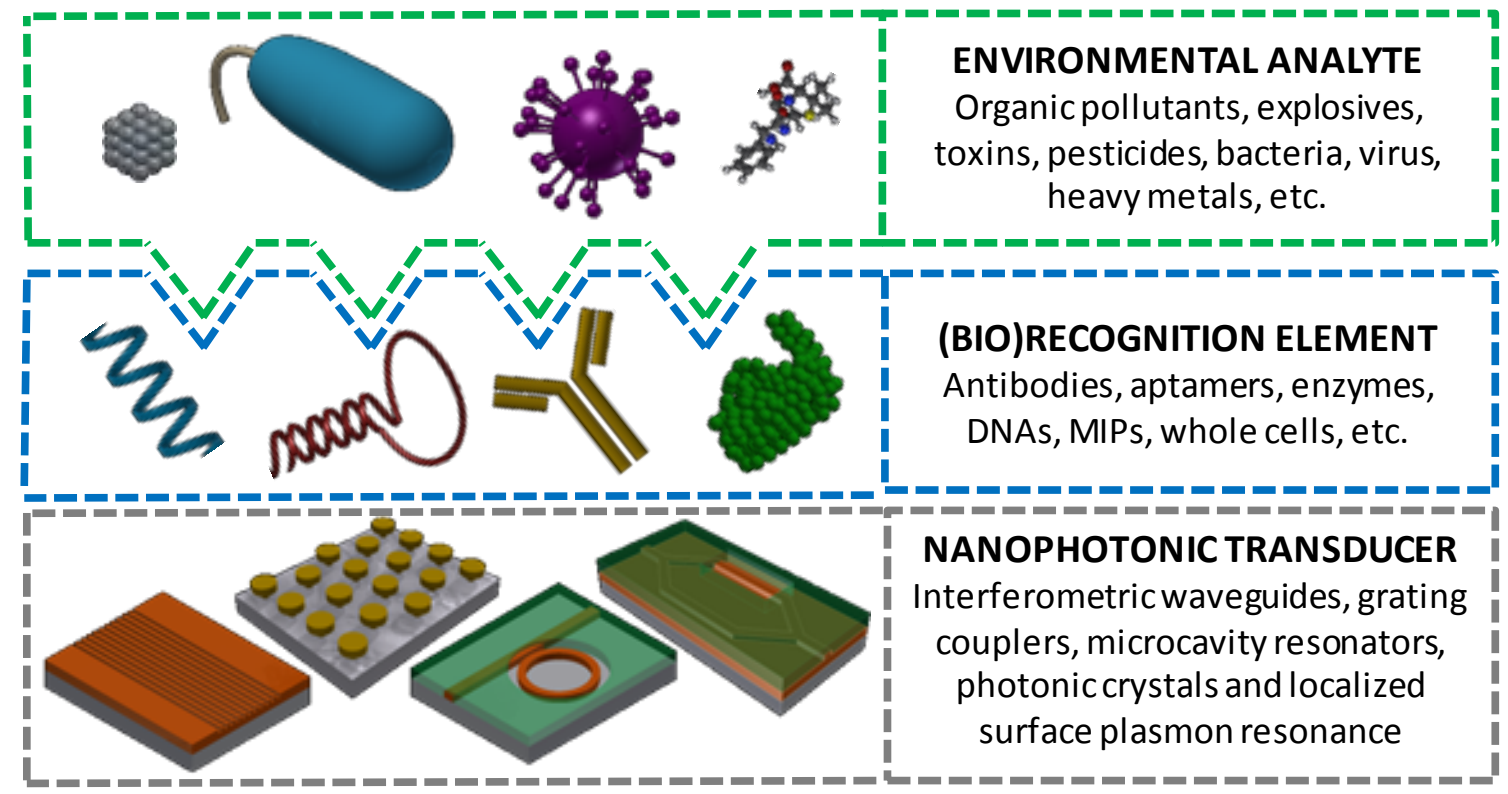

Figure 1. Schematic representation of the nanophotonic transducers and (bio)recognition elements constituting a biosensor device and the main types of environmental analytes to be detected. The (bio)recognition elements represented from left to right are: DNA/RNA strands, aptamer, antibody and enzyme. The nanophotonic transducers represented from left to right are: gratings coupler, Localized Surface Plasmon Resonance nanostructures, microcavity resonator and Mach-Zehnder interferometer.

Regarding the transducer, the most employed are based on electrochemical and optical principles. For those interested in electrochemical biosensors several reviews can be found in $[5,6]$. Optical transducers offer significant advantages as they can operate in a label-free scheme, avoiding the complicated labelling procedures and using fewer reagents, making the overall detection process shorter and cheaper. In addition, photonic biosensors offers other advantages, as the immunity to electromagnetic interferences, high sensitivity, wide bandwidth, and more importantly, the capacity of miniaturization and portability due to the scalable technologies employed for their fabrication [7].

Photonic biosensors take advantage of the evanescent wave detection, where the biological receptor layer is immobilized onto the core surface of a waveguide. The exposure of the functionalized surface to the complementary analyte and the subsequent biochemical interaction between them induces a local change in the optical properties of the waveguide 
transducer (in particular a change in the refractive index). This change is detected via the evanescent field of the guided light, and its amplitude can be correlated to the concentration of the analyte and to the affinity constant of the interaction, yielding a quantitative value of the interaction [7]. Moreover, photonic biosensors are easily integrated in lab-on-a-chip platforms by enabling combination of both fluidic handling and optical analysis onto a single chip.

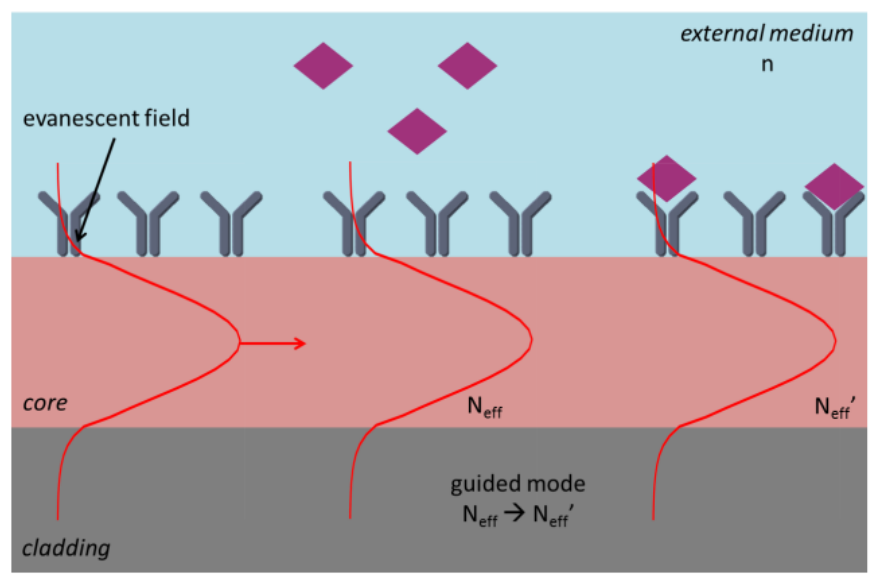

Figure 2. Evanescent wave sensing mechanism: a biomolecular interaction taking places on the surface between the biological receptor and its corresponding specific analyte is monitored through the electromagnetic evanescent field of the light traveling in the waveguide transducer. The (bio)recognition elements are represented as antibodies and the purple rectangles represent the analyte to be sensed which is contained in the sample (external medium). When the interaction takes place between the receptor and the analyte, the evanescent wave of the light traveling inside the core of the optical transducer will be affected by the increase in the refractive index on the sensor surface, therefore modifying its effective refractive index. The change in the effective refractive index can be directly correlated to the concentration of the analyte contained in the sample.

In this review we summarize the last achievements that the technology of nanophotonic labelfree biosensors is bringing to the environmental monitoring, with an especial emphasis in the main results from the last two years. We will provide an overview of the main technologies and their working principle, as well their application and performance for environmental analysis of different types of pollutants even in complex matrix samples.

\section{Nanophotonic transducers for label-free environmental monitoring}

The most common optical label-free biosensor based on the evanescent wave detection principle is the Surface Plasmon Resonance (SPR) sensor [8,9], in which the variation of the reflectivity on a metallic layer in close contact with a biological media is continuously monitored. The SPR biosensor has been widely developed and commercialize. But this biosensor is difficult to miniaturise and to be converted in a portable tool, and has a limited number of channels to perform multiplexed measurements. During last years the field of optical biosensors has been fueled with more competitive nanophotonic transducers, mainly based on compact waveguide nanostructures, which will be described in the following.

\section{Interferometric waveguide biosensors}

The working principle of an interferometric biosensor relies in the creation of an interference pattern, generated by the superposition of two or more light waves [10] in a waveguide. In a 
common interferometric device, the incoming light beam is split in two beams of equal intensity that travel through different optical paths (arms) defined in the waveguides. For biosensing applications, one of the arms is used as a reference while the other acts as a sensing one. The most common interferometric waveguide biosensors are the Mach-Zehnder Interferometer (MZI) and the Young Interferometer (YI). In a $\mathrm{MZI}$ the two waveguide arms are recombined before arriving at a detector, which collected the interferometric signal. In a YI reference and sensing arms are not recombined before the output. They are out-coupled individually and the interference pattern is generated off-chip. Recently, a new interferometric version, with a common path waveguide, called Bimodal Waveguide Interferometer (BiMW), has been introduced. In this device, the interference pattern at the output is generated by the interference of two transversal modes with the same polarization traveling in the same waveguide, rendering in a more compact and miniaturised device [7]. Interferometric devices are generally fabricated using standard microelectronics technology which allows the fabrication of compact sensors array in a miniaturised format as can be appreciated in Figure 3 .

MZI biosensors have been applied to the analysis of pollutants and pathogens of environmental relevance. A recent article shows a $\mathrm{MZI}$ immunosensor for the detection of Listeria monocytogenes, a pathogen found in soil, water and vegetation that can be lethal for humans. The biosensor achieves a limit of detection (LOD) of $10^{5} \mathrm{CFU} / \mathrm{mL}$, below the infection dose and shows high specificity over other pathogens [11]. Recent studies report MZI immunosensors for the detection of mycotoxins (e.g. aflatoxin $\mathrm{M} 1$ or ochratoxin $\mathrm{A}$ ), secondary toxic metabolites produced by fungus. The detection of these mycotoxins is not only relevant for food monitoring but also for environmental control, because they are contaminants in indoor environments such as water-damaged houses. The company LioniX International (Lionix International; URL: http://www.lionixbv.nl/) has described as a proof-of-concept, an asymmetric MZI (aMZI) immunosensor for the detection of aflatoxin M1, a cancer-causing chemical regulated by the European Commission (EC No. 1881/2006). Although the LOD (3 $\mathrm{ng} / \mathrm{mL}$ ) needs to be improved in order to fit with the European regulation (maximum residue level (MRL) is $50 \mathrm{ng} / \mathrm{L}$ in milk) the study proves the great potential of an aMZI device as a miniaturised analytical tool for label-free detection of aflatoxin in milk [13]. Pagkali et al. has developed a MZI immunosensor for the detection of Ochratoxin A, one of the most-abundant food-contaminating mycotoxins, with a LOD of $0.25 \mathrm{ng} / \mathrm{mL}$. The biosensor was applied to the analysis of Ochratoxin A directly in beer samples (LOD $2.0 \mathrm{ng} / \mathrm{mL}$ ) but the same immunosensor can be applied for water quality control. Even though LC/MS-MS methods reach LOD around $0.005-0.1 \mathrm{ng} / \mathrm{mL}$, they employ complex sample preparation procedures that are not required with the MZI sensor [14]. Another company, Optiqua Technologies (Optiqua Technologies, URL: http://www.optiqua.com/), has developed a MZI, the MiniLab'M system, for water quality monitoring. A recent article applies the MiniLab ${ }^{\mathrm{TM}}$ system for the detection of bisphenol A, a severe endocrine disruptor, in treated water [15].

One of the earliest applications using a YI immunosensor was herpes virus detection. Its performance was verified in buffer and serum, detecting a concentration of 850 particles $/ \mathrm{mL}$ [16]. Its sensitivity is comparable to standard methods like PCR. Recently, using MIP as receptor, a proof-of-concept YI sensor was developed for the detection in pure water of melamine, known to cause kidney problems in humans and animals in the presence of cyanuric acid inside the body [17]. 
Under the European Commission's Seventh Framework Programme (FP7) the project "Biosensors, Reporters and Algal Autonomous Vessels for Ocean Operation" (BRAAVOO) is focused on the development of a device that integrates three types of biosensor platforms which, used individually or simultaneously, allow the real-time monitoring of a wide range of chemical pollutants and biological effects. One of these sensing modules are interferometric (BiMW/aMZI) nanoimmunosensors employed for the detection of several chemical pollutants, including Irgarol 1051, a commonly used antifouling paint for marine vessels with endocrine disruptors properties. Results show a LOD of $0.005 \mu \mathrm{g} / \mathrm{L}$ and an $\mathrm{IC}_{50}$ value of $0.06 \mu \mathrm{g} / \mathrm{L}$ for the interferometric immunosensor in sea water samples without any sample pre-treatment (Chocarro-Ruiz et al., submitted).
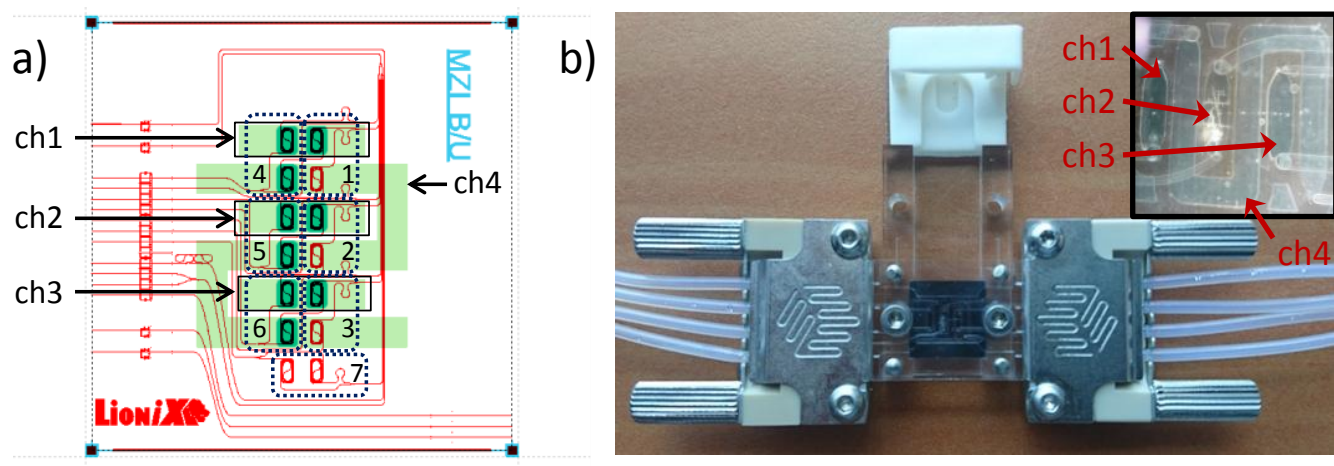

Figure 3. Example of an MZI array chip and its complementary microfluidic cell, designed by LioniX International.a) aMZI biosensor array chip scheme. The chip consists of 7 aMZIs (shown in the Fig. by dotted line regions): three of them (1-3) have a sensing window on top of the sensing arm (dark green regions), other three (4-6) have two sensing windows, one on top of each arm, and the seventh aMZI (7) is left covered by the cladding, to be used as a reference sensor. The fluidic paths in the cartridge are shown by pale green regions (ch1 - ch4); b) aMZI chip placed into a 4-channel microfluidic cell. (Inlet: detail of the microchannels over the sensing areas).

Table 1 summarizes the main achievements of interferometric waveguide biosensors for environmental monitoring.

Table 1. Recent results of interferometric waveguide biosensors for environmental monitoring.

\begin{tabular}{|c|c|c|c|c|c|}
\hline $\begin{array}{l}\text { Type of } \\
\text { sensor }\end{array}$ & $\begin{array}{c}\text { Recognition } \\
\text { element }\end{array}$ & Analyte & Matrix & $L O D$ & Reference \\
\hline $\mathrm{MZI}$ & $A b$ & $\begin{array}{l}\text { L. } \\
\text { monocytogenes }\end{array}$ & Buffer & $10^{5} \mathrm{CFU} / \mathrm{mL}$ & [11], 2014 \\
\hline aMZI & $\begin{array}{l}\mathrm{Ab} \\
\text { fragment }\end{array}$ & Aflatoxin M1 & Buffer & $3 \mathrm{ng} / \mathrm{mL}$ & [13], 2016 \\
\hline MZI & $A b$ & Ochratoxin A & $\begin{array}{l}\text { Buffer and } \\
\text { spiked beer } \\
\text { samples } \\
\text { diluted in } \\
\text { buffer }\end{array}$ & $2.0 \mathrm{ng} / \mathrm{mL}$ & [14], 2016 \\
\hline MZI & $A b$ & Bisphenol A & $\begin{array}{l}\text { Spiked pure/ } \\
\text { tap water } \\
\text { samples }\end{array}$ & NA & [15], 2015 \\
\hline YI & $A b$ & Herpes virus & $\begin{array}{l}\text { Buffer and } \\
\text { spiked serum } \\
\text { samples }\end{array}$ & $\begin{array}{l}<850 \\
\text { particles/mL }\end{array}$ & {$[16], 2007$} \\
\hline YI & MIP & Melamine & Pure water & NA & [17], 2016 \\
\hline
\end{tabular}




\section{Grating biosensors}

A grating is a system of periodic or corrugated structures which allows the excitation of a light guided mode in a waveguide. When a specific angle of incidence of a light beam is applied on a grating, the incoupling condition is reached and the light is propagating through the waveguide. The incoupling angle is very sensitive to any perturbation in the surface of the waveguide due the interaction through the evanescent field. The company Microvacuum Ltd. (Microvacuum Ltd.; URL: http://www.owls-sensors.com/) commercializes devices based on this technology, measuring the incoupling angle of a polarized laser light, called Optical Waveguide Lightmode Spectroscopy System (OWLS).

Early work showed the performance of an OWLS immunosensor for the detection of the herbicide trifluralin, listed by de European Union as endocrine disrupter. This biosensor improves the LOD $(1 \mathrm{fg} / \mathrm{mL})$ in six orders of magnitude as compared to the enzyme-linked immunosorbent assay (ELISA) test [18]. More recent investigations are focused on the sensing of mycotoxins such as deoxynivalenol [19], and aflatoxin B1 and ochratoxin A in flour [20] or zearalenone in ground corn [21]. The biosensors show similar or improved sensitivities than standard ELISA test, and specially, the OWLS biosensor for ochratoxin A detection reaches a better LOD compared with the MZI biosensor previously described [14]. The OWLS biosensors have also been applied for the detection of vitellogenin, an egg yolk protein precursor used as biomarker of endocrine disrupting effects in carp [21,22] and amphibian species [23]. Additionally, a proof-of-concept device has been developed using biosilica expressed in genetically modified $E$. coli for the attachment onto the sensor surface. The whole cell receptor was described for the detection of penicillin $\mathrm{G}$ (antibiotic), chloramphenicol (antibiotic), carbofuran (pesticide) and $\mathrm{H}_{2} \mathrm{O}_{2}$ [24]. Finally, OWLS technology has also been applied for the label-free detection of Salmonella typhimurium [25] and Legionella pneumophila [26] in water, using antibodies as biorecognition elements.

A summary of the employment of grating biosensors for pollutants detections can be found in Table 2.

Table 2. Recent results of grating biosensors for environmental monitoring.

\begin{tabular}{ccccc}
\hline $\begin{array}{c}\text { Recognitio } \\
\text { n element }\end{array}$ & \multicolumn{1}{c}{ Analyte } & \multicolumn{1}{c}{ Matrix } & LOD & Reference \\
\hline $\mathrm{Ab}$ & Trifluralin & $\begin{array}{l}\text { Pure water, tap } \\
\text { water and field } \\
\text { surface water } \\
\text { samples } \\
\text { Buffer and spiked } \\
\text { wheat flour }\end{array}$ & $1 \mathrm{fg} / \mathrm{mL}$ & [18], 2003 \\
$\mathrm{Ab}$ & Deoxynivalenol & & \\
& & $\begin{array}{l}\text { samples (60\% } \\
\text { acetonitrile) } \\
\text { Buffer and spiked } \\
\text { barley and wheat }\end{array}$ & $0.5 \mathrm{ng} / \mathrm{mL}$ & [20], 2007 \\
$\mathrm{Ab}$ & Aflatoxin B1 and & &
\end{tabular}




\begin{tabular}{|c|c|c|c|c|}
\hline $\mathrm{Ab}$ & Zearalenone & $\begin{array}{l}\text { Spiked ground corn } \\
\text { samples ( } 60 \% \\
\text { acetonitrile) }\end{array}$ & NA & {$[21], 2009$} \\
\hline$A b$ & Vitellogenin & $\begin{array}{l}\text { Carp liver diluted in } \\
\text { buffer and serum } \\
\text { samples }\end{array}$ & $0.07 \mathrm{ng} / \mathrm{mL}$ & {$[22], 2013$} \\
\hline$A b$ & Vitellogenin & $\begin{array}{l}\text { Heart, liver and } \\
\text { gonad samples } \\
\text { diluted in buffer }\end{array}$ & $0.1 \mathrm{ng} / \mathrm{mL}$ & {$[23], 2015$} \\
\hline $\begin{array}{l}\text { Whole Cell } \\
\text { (modified } \\
\text { E. coli) }\end{array}$ & $\begin{array}{l}\text { Penicillin G, } \\
\text { chloramphenicol; } \\
\text { carbofuran and } \\
\mathrm{H}_{2} \mathrm{O}_{2}\end{array}$ & Buffer & NA & {$[24], 2013$} \\
\hline$A b$ & S. typhimurium & Buffer & $\begin{array}{l}1.3 \times 10^{3} \\
\mathrm{CFU} / \mathrm{mL}\end{array}$ & [25], 2007 \\
\hline$A b$ & L. pneumophila & $\begin{array}{l}\text { Spiked water } \\
\text { samples }\end{array}$ & $\begin{array}{l}1.3 \times 10^{4} \\
\mathrm{CFU} / \mathrm{mL}\end{array}$ & {$[26], 2009$} \\
\hline
\end{tabular}

\section{Microcavity resonator biosensors}

In a microcavity resonator, the light of a specific wavelength is coupled into a circular waveguide through the use of an external coupler. The confined light in the microcavity is propagated in the form of whispering gallery modes (WGM). Any perturbation on the waveguide microcavity surface taking places in the evanescent area induces a shift in the coupled light wavelength, and therefore this structure is an excellent candidate for biosensing applications [27].

The quality $Q$ factor of the microring, which is proportional to the number of times the light circulates within the microcavity, influences notably in the sensitivity of the sensor and, therefore, high $Q$ factors are the preferred ones [28]. This has been confirmed by the single molecule detection of influenza A virions in air [29] or single nucleic acid interactions [30] employing high Q-factors microring biosensors. Moreover, these sensors are fabricated with standard microelectronics technology and can be miniaturised even in an high multiplexed array format for multiple analysis [7].

Recently, WGM biosensors were used for the detection of heavy metals. An aptasensor for mercury (II) ion detection was developed showing high affinity for $\mathrm{Hg}^{2+}$ ions over eight common metal ions, reaching close $\sim 1 \mathrm{ng} / \mathrm{mL}$ LOD. Drawbacks are some possible unspecific interactions and slower responses when the $\mathrm{Hg}^{2+}$ concentration decreases [31]. Another biosensor using glutathione as receptor was developed for $\mathrm{Pb}$ (II) detection, showing a LOD of $10 \mathrm{pg} / \mathrm{mL}$, which is significantly lower of what was previously reported, and even in the presence of alkaline and heavy metal interferences [32].

A novel approach for transducer biofunctionalization, as a proof-of-concept for antidinitrophenol Ab detection, was developed by Bog et al. [33]. Using a polymer (PDMS) stamp, patterned by polymer pen lithography, the sensor surface was functionalized with 2,4-

Dinitrophenol, a hazardous pollutant used as pesticide and in the production of sulphur dyes. 
This novel functionalization approach allows multiplexing analysis as it shows the possibility to individually functionalize each cavity on a densely packed chip. Yang et al. developed a microcavity resonator for the detection of organophosphorus pesticide parathion-methyl, monitoring with enhanced analysis times compared to standard techniques, achieving LOD in line with the admissible levels [34].

Another important research field in environmental monitoring is the detection of biological or chemical warfare agents. A proof-of concept using a microring resonator was developed for ricin and saporin detection [35]. Bonnot et al reported a WGM sensor for the detection of dimethyl methylphosphonate (DMMP), a precursor of Sarin nerve gas in air [36].

Recent works include a WGM aptasensor for the detection of mycotoxin aflatoxin M1 [37]. Ghali et al. report a WGM biosensor for the detection of Staphylococcus aureus with a phage protein as receptor [38]. An earlier work illustrates a proof-of-concept for $E$. coli detection obtaining a high LOD $\left(10^{5} \mathrm{CFU} / \mathrm{mL}\right)$, probably due to a suboptimal Ab functionalization [39]. Microcavity resonator immunosensors have also been employed for virus detection $[40,41]$. All the above results demonstrate the great potential that this transducer offers for the detection of a wide range of hazards and its suitability using different receptors.

Table 3 summarizes the last advances reported using microcavity resonator biosensors for environmental monitoring.

Table 3. Recent results of microcavity resonator biosensors for environmental monitoring.

\begin{tabular}{|c|c|c|c|c|}
\hline $\begin{array}{c}\text { Recognition } \\
\text { element }\end{array}$ & Analyte & Matrix & $L O D$ & Reference \\
\hline Aptamer & $\mathrm{Hg}^{2+}$ & Buffer & $\sim 1 \mathrm{ng} / \mathrm{mL}$ & [31], 2016 \\
\hline Glutathione & $\mathrm{Pb}^{2+}$ & Pure water & $10 \mathrm{pg} / \mathrm{mL}$ & {$[32], 2014$} \\
\hline $\mathrm{Ab}$ & 2,4-Dinitrophenol & Buffer & NA & [33], 2014 \\
\hline $\begin{array}{l}\text { AChE } \\
\text { enzyme }\end{array}$ & Parathion-methyl & Buffer & $10 \mathrm{pg} / \mathrm{mL}$ & {$[34], 2008$} \\
\hline $\mathrm{Ab}$ & Ricin and saporin & Buffer & $\begin{array}{l}200 \mathrm{pM} \\
(\sim 12 \mathrm{ng} / \mathrm{mL}) \\
\text { (ricin) }\end{array}$ & [35], 2013 \\
\hline $\begin{array}{l}\text { Modified } \\
\text { odorant- } \\
\text { binding } \\
\text { proteins }\end{array}$ & $\begin{array}{l}\text { DMMP (precursor } \\
\text { of Sarin) }\end{array}$ & $\begin{array}{l}\text { Spiked gas } \\
\text { samples }\end{array}$ & $6.8 \mathrm{ng} / \mathrm{mL}$ & {$[36], 2014$} \\
\hline Aptamer & Aflatoxin M1 & Buffer & NA & [37], 2015 \\
\hline $\begin{array}{l}\text { Phage } \\
\text { protein }\end{array}$ & S. aureus & Buffer & $\begin{array}{l}5 \times 10^{6} \\
\mathrm{CFU} / \mathrm{mL}\end{array}$ & [38], 2016 \\
\hline $\mathrm{Ab}$ & E. coli & Buffer & $10^{5} \mathrm{CFU} / \mathrm{mL}$ & [39], 2008 \\
\hline$A b$ & $\begin{array}{l}\text { Bean pod mottle } \\
\text { virus }\end{array}$ & $\begin{array}{l}\text { Buffer and } \\
\text { real field } \\
\text { complex } \\
\text { leaf } \\
\text { extracts } \\
\text { samples } \\
\text { diluted in } \\
\text { buffer }\end{array}$ & $10 \mathrm{ng} / \mathrm{mL}$ & {$[40], 2012$} \\
\hline
\end{tabular}




\begin{tabular}{llll} 
Ab M13 bacteriophage Buffer $\quad \begin{array}{l}2.3 \times 10^{3} \\
\text { PFU } / \mathrm{mL}\end{array} \quad[41], 2008$ \\
\hline
\end{tabular}

\section{Photonic crystal biosensors}

A photonic crystal $(\mathrm{PhC}$ ) is a device composed by different refractive index materials disposed as periodic nanostructures. This periodicity affects the propagation of electromagnetic waves and generates a photonic bandgap, i.e. range of wavelengths which are not propagated. If a defect is introduced in the nanostructure, the photonic bandgap is disturbed, thus $\mathrm{PhC}$ can be used as a sensor.

Recently PhCs have emerged as a promising label-free class of biosensors [42]. While still at an early stage, some articles already report the potential of these nanophotonic sensors for environmental monitoring. One of the first works reports a $\mathrm{PhC}$ immunosensor for detecting porcine rotavirus in partially purified water samples with similar sensitivity to ELISA assay [43]. Takahashi et al. developed a PhC sensor for the detection of endotoxins in pure water, based on the limulus amebocyte lysate (LAL) reaction. This biosensor could be applied for gramnegative bacteria detection as endotoxins are lipopolysaccharides present in their membrane [44].

Yan et al. reported a PhC immunosensor for the detection of gentamicin, an antibiotic used to treat different types of bacterial infections. The sensor exhibits specificity over vancomycin and tobramycin but it has only been tested in buffer conditions ( $\mathrm{Yan} \mathrm{H}$, et al., abstract in Proceedings of CLEO (OSA), San Jose, CA. May 2015:STu4K.2). The most recent development is a $\mathrm{PhC}$ biosensor for cadmium detection, allowing the detection of cadmium-EDTA-BSA conjugate as low as $5 \mathrm{ng} / \mathrm{mL}$ (Yan $\mathrm{H}$ et al., abstract in SPIE BiOS, San Francisco, CA. April 2016:972507-972507).

Table 4 summarizes last advances in PhC biosensor for environmental monitoring applications.

Table 4. Recent results of Photonic Crystal based biosensors for environmental monitoring.

\begin{tabular}{lllll}
\hline $\begin{array}{c}\text { Recognition } \\
\text { element }\end{array}$ & \multicolumn{1}{c}{ Analyte } & \multicolumn{1}{c}{ Matrix } & LOD & Reference \\
\hline $\mathrm{Ab}$ & $\begin{array}{l}\text { Porcine } \\
\text { rotavirus }\end{array}$ & $\begin{array}{l}\text { Partially } \\
\text { purified } \\
\text { spiked water }\end{array}$ & $36 \mathrm{FFU} / \mathrm{mL}$ & {$[43], 2009$} \\
& & $\begin{array}{l}\text { samples } \\
\text { Pure water }\end{array}$ & $0.0001 \mathrm{EU} / \mathrm{mL}$ & {$[44], 2015$} \\
$\mathrm{LAL}$ & Endotoxin & Buffer & $<0.1 \mathrm{ng} / \mathrm{mL}$ & $2015^{\mathrm{a}}$ \\
$\mathrm{Ab}$ & $\begin{array}{l}\text { Gentamicin } \\
\text { Cadmium- } \\
\mathrm{Ab}\end{array}$ & $\mathrm{NA}$ & $5 \mathrm{ng} / \mathrm{mL}$ & $2016^{\mathrm{b}}$ \\
& $\begin{array}{l}\text { chelate } \\
\text { conjugate }\end{array}$ & & & \\
\hline
\end{tabular}

aYan $\mathrm{H}$ et al., abstract in Proceedings of CLEO (Optical Society of America), San Jose, CA. May 2015:STu4K.2

byan H et al., abstract in SPIE BiOS San Francisco, CA. April 2016:972507972507 
The interaction of light waves with metal nanostructures, smaller than the incident wavelength, generates a resonance phenomenon called Localized Surface Plasmon Resonance (LSPR). The LSPR biosensors are considered as the next generation of SPR sensing platforms. Also, they show great potential for integration and miniaturization, as well as, high sensitivity and multiplexed capabilities $[45,46]$.

A recent publication illustrates the development of a fibre optic LSPR sensor using MIP as receptor for the detection of 2,4,6-trinitrotoluene (TNT), a nitroaromatic explosive. The performance of this sensor is not optimal since the LOD achieved was $0.16 \mu \mathrm{g} / \mathrm{mL}$, well above the limit proposed by the Environmental Protection Agency (EPA) $(2.0 \mathrm{ng} / \mathrm{mL}$ in drinking water). Further improvements should be required to obtain a competitive device for environmental applications but outstands as one of the few biosensors employing MIPs as receptors [47]. Kawaguchi et al. developed a LSPR immunosensor showing better LOD (10 $\mathrm{pg} / \mathrm{mL}$ ) for TNT detection [48]. Another MIP LSPR sensor recently was developed for the detection of tetracycline, a common antibiotic used in marine aquaculture. The sensor was fabricated by immobilizing silver nanoparticles over an unclad core of a multimode optical fibre, achieving a LOD of $1 \mathrm{ng} / \mathrm{mL}$ in Milli-Q water [49], the lowest compared to other approaches reported in the literature. However, silver has the disadvantage of being chemically unstable and the performance when working with real samples needs to be evaluated [50]. Another common pharmacologically active substance to be found in various environmental waters is stanozolol, a synthetic anabolic steroid. A LSPR immunosensor for stanozolol detection was developed achieving a LOD of $0.7 \mathrm{ng} / \mathrm{mL}$ [51]. This one is comparable to a conventional SPR, but above the LOD $(0.25 \mathrm{pg} / \mathrm{mL})$ achieved with liquid chromatography tandem mass spectrometry in aqueous matrix (LC-MS/MS) [52]. 5-fluorouracil, an antineoplastic drug used in cancer therapy, is an emerging pollutant in aquatic environments [53]. To detect 5-fluorouracil, a LSPR immunosensor was developed reaching a LOD of $10 \mathrm{ng} / \mathrm{mL}$, similar to the ELISA test[54]. LSPR sensors for pesticide detection like paraoxon, using acetylcholinesterase enzyme as receptor [55], or an atrazine immunosensor [56] have also been developed.

Several articles have focused on the development of LSPR sensors for virus detection, including small enveloped RNA viruses (vesicular stomatitis virus (VSV) and pseudo typed Ebola), or large enveloped DNA viruses (vaccinia virus) directly from biological media [57]. A LSPR sensor for the detection of VSV, which can infect cattle or horses, shows a LOD of $<10^{5} \mathrm{PFU} / \mathrm{mL}$ from biological media (cell growth medium $+7 \%$ fetal calf serum). Other immunosensors were developed for the detection of influenza virus [58], dengue virus [59] and orchid viruses [60].

The extracellular adherence protein (EAP), found on the outer surface of the bacterium $S$. aureus, was detected using a LSPR immunosensor, with a LOD of $8 \mathrm{pM}(\sim 0.45 \mathrm{ng} / \mathrm{mL})$ [61]. Zhu et al. developed a LSPR Au-Ag nanoparticles sensor for the detection of $S$. aureus enterotoxin $B$ using a direct immunoassay. A concentration of $0.1 \mathrm{ng} / \mathrm{mL}$ is already too low to be directly detected due to the low amplitude of spectrum [62]. Finally, a LSPR biosensor was developed for the multiplex detection of a range of pathogenic bacteria (Vibrio vulnificus, Salmonella spp., Staphylococcus aureus, Enterococcus faecalis, Neisseria gonorrhoea, Staphylococcus epidermidis and Klebsiella oxytoca) using DNA probes as receptors [63]. 
Table 5 provides some representative LSPR biosensors for pollutants detection.

Table 5. Recent LSPR biosensors for environmental monitoring.

\begin{tabular}{|c|c|c|c|c|}
\hline $\begin{array}{c}\text { Recognition } \\
\text { element }\end{array}$ & Analyte & Matrix & $L O D$ & Reference \\
\hline MIP & TNT & Pure water & $0.16 \mu \mathrm{g} / \mathrm{mL}$ & [47], 2015 \\
\hline$A b$ & TNT & Buffer & $10 \mathrm{pg} / \mathrm{mL}$ & {$[48], 2008$} \\
\hline MIP & Tetracycline & Pure water & $1 \mathrm{ng} / \mathrm{mL}$ & [49], 2015 \\
\hline $\mathrm{Ab}$ & Stanozolol & Buffer & $0.7 \mathrm{ng} / \mathrm{mL}$ & {$[51], 2008$} \\
\hline$A b$ & 5-fluorouracil & NA & $10 \mathrm{ng} / \mathrm{mL}$ & {$[54], 2010$} \\
\hline Enzyme & Paraoxon & Buffer & $0.234 \mathrm{ng} / \mathrm{mL}$ & {$[55], 2006$} \\
\hline $\mathrm{Ab}$ & Atrazine & Buffer & $10 \mathrm{ng} / \mathrm{mL}$ & {$[56], 2014$} \\
\hline$A b$ & $\begin{array}{l}\text { VSV, pseudo typed } \\
\text { Ebola and vaccinia } \\
\text { virus }\end{array}$ & $\begin{array}{l}\text { Buffer and } \\
\text { spiked } \\
\text { biological } \\
\text { media }\end{array}$ & $\begin{array}{l}<10^{5} \\
\mathrm{PFU} / \mathrm{mL}\end{array}$ & [57], 2010 \\
\hline$A b$ & Influenza virus & Buffer & $1 \mathrm{pg} / \mathrm{mL}$ & [58], 2012 \\
\hline$A b$ & Dengue virus & Buffer & NA & [59], 2013 \\
\hline$A b$ & $\begin{array}{l}\text { Cymbidium mosaic } \\
\text { virus and } \\
\text { Odontoglossum } \\
\text { ringspot virus }\end{array}$ & $\begin{array}{l}\text { Buffer and } \\
\text { real field } \\
\text { plant crude } \\
\text { saps } \\
\text { samples } \\
\text { diluted in } \\
\text { buffer }\end{array}$ & $\begin{array}{l}48 \mathrm{pg} / \mathrm{mL} \\
\text { and } 42 \\
\mathrm{pg} / \mathrm{mL} \\
\text { respectively }\end{array}$ & {$[60], 2014$} \\
\hline$A b$ & EAP from S. Aureus & Buffer & $\begin{array}{l}8 \mathrm{pM}(\sim 0.45 \\
\mathrm{ng} / \mathrm{mL})\end{array}$ & [61], 2009 \\
\hline$A b$ & $\begin{array}{l}\text { S. aureus } \\
\text { enterotoxin B }\end{array}$ & Buffer & NA & {$[62], 2009$} \\
\hline DNA & $\begin{array}{l}\text { Pathogenic bacteria } \\
\text { DNA }\end{array}$ & Pure water & $10 \mathrm{fM}$ & {$[63], 2011$} \\
\hline
\end{tabular}

\section{Conclusions and future perspectives}

Nanophotonic biosensors based on evanescent wave detection can offer label-free, real-time, sensitive, selective, multiplex, rapid, and inexpensive analyses; the main five technologies discussed in this review (interferometric sensors, grating couplers, microcavity resonators, photonic crystal based sensors and localised surface plasmon resonance) have advantages and disadvantages, and depending on the final application one can be more suitable than another. The main differences between all of them rely in terms of sensitivity and their ability for integration in compact platforms. Sensitivity for label-free detection in real samples is a must and one of the most suitable ones are the interferometric sensors, which have shown outstanding levels of sensitivity. The photonic crystal and the LSPR sensors have shown the most limited sensitivity for a direct and one-step label-free detection. Grating couplers and microcavity sensors exhibit an intermediate level of sensitivity. On the other hand, the fabrication of LSPR and grating couplers sensors is usually less complex and cheaper, while the fabrication of interferometric, microcavity and photonic crystal sensors is more complex, requiring dedicated foundries. However, they have the additional advantage of providing microchip arrays with multiplex sensors of identical performances.

The level of specificity, selectivity and accuracy which can be achieved with the photonic 
biosensor technology for environmental applications is mainly related to the bioreceptor employed and the biofunctionalization protocol, rather than due to the transducer itself. Key factors are the ability of getting a complete specific bioreceptor against the pollutant or toxin to be detected, to employ a biofunctionalization protocol which preserves the activity and the functionality of the bioreceptor once attached to the sensor surface, and to ensure antifouling properties of the bioreactor layer for detecting directly in real matrices. Although many of the applications for environmental monitoring have been demonstrated in buffer conditions, the biosensor technology shows great performance in terms of selectivity and sensitivity and some have been successfully applied to spiked samples with excellent performance and accuracy. Taking into account the strong development in antifouling biofunctionalization techniques for biosensor surfaces, there is no doubts that the technology could be employed for real sample evaluation in the near future.

During last years photonic biosensors have shown its capabilities for multiplexing and miniaturisation in compact platforms as laboratory proof-of-concept prototypes; there is no doubt that this novel nanophotonic technology soon will surpass the laboratory stage and will hit the market. This biosensor market was valued at \$11.39 Billion in 2013 and is forecast to double by 2020 significantly driven by the growing need for environmental surveillance and the emergence of nanobiosensors (Markets and Markets, URL:

http://www.marketsandmarkets.com/Market-Reports/biosensors-market-798.html). Moreover, due the fast growing of mobile technology as tablets and smartphones, probably in the near future a nanophotonic label-free biosensor can be integrated within these gadgets. Thus, such tools for portable analysis and early warning systems in environmental monitoring could be distributed around the world, helping to control the serious problem of the environmental pollution.

\section{Acknowledgements}

This work has been funded by the 7FP (EU, BRAAVOO Grant Agreement No 614010). The nanoB2A is a consolidated research group (Grup de Recerca) of the Generalitat de Catalunya and has support from the Departament d'Universitats, Recerca i Societat de la Informació de la Generalitat de Catalunya (2014 SGR 624). ICN2 acknowledges support of the Spanish MINECO through the Severo Ochoa Centers of Excellence Program under Grant SEV-2013-0295. We thank LioniX International for supplying Figure 3.

\section{References}

1. Rodriguez-Mozaz S, Lopez de Alda MJ, Barceló D: Advantages and limitations of on-line solid phase extraction coupled to liquid chromatography-mass spectrometry technologies versus biosensors for monitoring of emerging contaminants in water [Internet]. J. Chromatogr. A 2007, 1152:97-115.

2. Long F, Zhu A, Gu C: Recent Progress in Optical Biosensors for Environmental Applications [Internet]. In State of the Art in Biosensors - Environmental and Medical Applications. . 2013:3-28.

3. Van Dorst B, Mehta J, Bekaert K, Rouah-Martin E, De Coen W, Dubruel P, Blust R, Robbens J: Recent advances in recognition elements of food and environmental biosensors: A review. Biosens. Bioelectron. 2010, 26:1178-1194.

4. Conroy PJ, Hearty S, Leonard P, O'Kennedy RJ: Antibody production, design and use for biosensor-based applications [Internet]. Semin. Cell Dev. Biol. 2009, 20:10-26.

5. Ronkainen NJ, Halsall HB, Heineman WR: Electrochemical biosensors [Internet]. Chem. 
Soc. Rev. 2010, 39:1747-1763.

6. Grieshaber D, Mackenzie R, Vörös J, Reimhult E: Electrochemical Biosensors -Sensor Principles and Architectures [Internet]. Sensors 2008, 8:1400-1458.

- This comprehensive review introduces the traditional electrochemical devices (amperometric, potentiometric and conductometric) to later emphasize on the different types of surface nano-architectures. The review highlights the importance of nanotechnology and how is fundamental to complement with different types of sensing methods for characterization

7. Estevez MC, Alvarez M, Lechuga LM: Integrated optical devices for lab-on-a-chip biosensing applications [Internet]. Laser Photon. Rev. 2012, 6:463-487.

8. Nguyen HH, Park J, Kang S, Kim M: Surface plasmon resonance: A versatile technique for biosensor applications [Internet]. Sensors 2015, 15:10481-10510.

9. Homola J: Surface plasmon resonance sensors for detection of chemical and biological species. [Internet]. Chem. Rev. 2008, 108:462-493.

- This outstanding review introduces the principles, based on evanescence wave detection, of surface plasmon resonance sensors. A review of the last technological advances and a summary of the different applications for biological or chemical detection in healthcare, environmental monitoring, and food security

10. Kozma P, Kehl F, Ehrentreich-Förster E, Stamm C, Bier FF: Integrated planar optical waveguide interferometer biosensors: A comparative review. Biosens. Bioelectron. 2014, 58:287-307.

11. Sarkar D, Gunda NSK, Jamal I, Mitra SK: Optical biosensors with an integrated MachZehnder Interferometer for detection of Listeria monocytogenes [Internet]. Biomed. Microdevices 2014, 16:509-520.

13. Chalyan T, Guider R, Pasquardini L, Zanetti M, Falke F, Schreuder E, Heideman RG, Pederzolli C, Pavesi L: Asymmetric Mach-Zehnder interferometer based biosensors for Aflatoxin M1 detection [Internet]. Biosensors 2016, 6:1.

14. Pagkali V, Petrou PS, Salapatas A, Makarona E, Peters J, Haasnoot W, Jobst G, Economou A, Misiakos K, Raptis I, et al.: Detection of ochratoxin A in beer samples with a label-free monolithically integrated optoelectronic biosensor. J. Hazard. Mater. 2016, doi:10.1016/j.jhazmat.2016.03.019.

15. Ma K, Ekblad T, Koerkamp MK, Kelderman H, Wijlen M van, Duarah A, Yue J, Zhang L, Wong MV-M, Lim MH: Contaminant detection in treated water using Optiqua's MiniLab ${ }^{\mathrm{TM}}$ biosensing system: a case study for Bisphenol A [Internet]. Int. J. Environ. Anal. Chem. 2015, 95:366-378.

This article illustrates the development of an immunosensor for Bisphenol A detection. This is one of the first articles that employs an integrated sensor already marketed, the MiniLab ${ }^{\mathrm{TM}}$ developed by Optiqua technologies for environmental monitoring. The interferometric waveguide sensor is even tested in tap water samples spiked with known BPA concentrations at $\mu \mathrm{g} / \mathrm{L}$ level and applied to the analysis of up to 12 different water matrices collected from different waterworks and treatment plants.

16. Ymeti A, Greve J, Lambeck P V, Wink T, Van Hövell SW, Beumer TA, Wijn RR, Heideman 
RG, Subramaniam V, Kanger JS: Fast, ultrasensitive virus detection using a young interferometer sensor [Internet]. Nano Lett. 2007, 7:394-397.

- This work reports one of the first and still one of the few developed young interferometer biosensors. The immunosensor detects herpes simplex virus type 1 in buffer and serum at very low concentrations ( 850 particles $/ \mathrm{mL}$ ).

17. Aikio S, Zeilinger M, Hiltunen J, Hakalahti L, Hiitola-Keinänen J, Hiltunen M, Kontturi V, Siitonen S, Puustinen J, Lieberzeit P, et al.: Disposable (bio)chemical integrated optical waveguide sensors implemented on roll-to-roll produced platforms [Internet]. RSC Adv. 2016, 6:50414-50422.

18. Székács A, Trummer N, Adányi N, Váradi M, Szendro I: Development of a non-labeled immunosensor for the herbicide trifluralin via optical waveguide lightmode spectroscopic detection. Anal. Chim. Acta 2003, 487:31-42.

19. Majer-Baranyi K, Székács A, Szendro I, Kiss A, Adányi N: Optical waveguide lightmode spectroscopy technique-based immunosensor development for deoxynivalenol determination in wheat samples. Eur. Food Res. Technol. 2011, 233:1041-1047.

20. Adányi N, Levkovets IA, Rodriguez-Gil S, Ronald A, Váradi M, Szendro I: Development of immunosensor based on OWLS technique for determining Aflatoxin B1 and Ochratoxin A. Biosens. Bioelectron. 2007, 22:797-802.

21. Székács A, Adányi N, Székács I, Majer-Baranyi K, Szendrő I: Optical waveguide lightmode spectroscopy immunosensors for environmental monitoring [Internet]. Appl. Opt. 2009, 48:B151-B158.

- The Optical Waveguide Lightmode Spectroscopy System immunosensor device developed by Microvacuum Ltd is presented. The performance of the device for environmental monitoring is tested by the detection of trifluralin in apple juice, zearalenone in corn samples and vitellogenin in carp.

22. Adányi N, Majer-Baranyi K, Nagy A, Németh G, Szendro I, Székács A: Optical waveguide lightmode spectroscopy immunosensor for detection of carp vitellogenin. Sensors Actuators, B Chem. 2013, 176:932-939.

23. Majer-Baranyi K, Adányi N, Nagy A, Bukovskaya O, Szendrő I, Székács A: Label-free immunosensor for monitoring vitellogenin as a biomarker for exogenous oestrogen compounds in amphibian species. Int. J. Environ. Anal. Chem. 2015, 95:481-493.

24. Adányi N, Bori Z, Szendro I, Erdélyi K, Wang X, Schröder HC, Müller WE: Bacterial sensors based on biosilica immobilization for label-free OWLS detection. $N$. Biotechnol. 2013, 30:493-499.

25. Kim N, Park IS, Kim WY: Salmonella detection with a direct-binding optical grating coupler immunosensor. Sensors Actuators, B Chem. 2007, 121:606-615.

26. Cooper IR, Meikle ST, Standen G, Hanlon GW, Santin M: The rapid and specific realtime detection of Legionella pneumophila in water samples using Optical Waveguide Lightmode Spectroscopy. J. Microbiol. Methods 2009, 78:40-44.

27. Wade JH, Bailey RC: Applications of Optical Microcavity Resonators in Analytical Chemistry [Internet]. Annu. Rev. Anal. Chem. 2016, 9:1-25. 
28. Foreman MR, Swaim JD, Vollmer F: Whispering gallery mode sensors [Internet]. Adv. Opt. Photonics 2015, 7:168-240.

29. He L, Özdemir ŞK, Zhu J, Kim W, Yang L: Detecting single viruses and nanoparticles using whispering gallery microlasers. [Internet]. Nat. Nanotechnol. 2011, 6:428-432.

30. Baaske MD, Foreman MR, Vollmer F: Single-molecule nucleic acid interactions monitored on a label-free microcavity biosensor platform. [Internet]. Nat. Nanotechnol. 2014, 9:933-939.

- - This article represents a breakthrough in biosensing achieving a long standing goal of label-free single-molecule nucleic acid interaction using a whispering gallery modes sensor. The article even reports the detection of very short, 8-mer oligonucleotides, strands $(\sim 2,350 \mathrm{Da})$.

31. Wu F, Wu Y, Niu Z, Vollmer F: Integrating a dna strand displacement reaction with a whispering gallery mode sensor for label-free mercury (II) ion detection. Sensors 2016, 16:1197.

32. Panich S, Wilson KA, Nuttall P, Wood CK, Albrecht T, Edel JB: Label-free Pb(II) whispering gallery mode sensing using self-assembled glutathione-modified gold nanoparticles on an optical microcavity. Anal. Chem. 2014, 86:6299-6306.

33. Bog U, Brinkmann F, Kalt H, Koos C, Mappes T, Hirtz M, Fuchs H, Köber S: Large-Scale Parallel Surface Functionalization of Goblet-type Whispering Gallery Mode Microcavity Arrays for Biosensing Applications [Internet]. Small 2014, 10:3863-3868.

34. Yang $G$, White IM, Fan X: An opto-fluidic ring resonator biosensor for the detection of organophosphorus pesticides. Sensors Actuators, B Chem. 2008, 133:105-112.

35. Shia WW, Bailey RC: Single domain antibodies for the detection of ricin using silicon photonic microring resonator arrays [Internet]. Anal. Chem. 2013, 85:805-810.

36. Bonnot K, Cuesta-Soto F, Rodrigo M, Varriale A, Sanchez N, D'Auria S, Spitzer D, LopezRoyo F: Biophotonic ring resonator for ultrasensitive detection of DMMP as a simulant for organophosphorus agents [Internet]. Anal. Chem. 2014, 86:5125-5130.

37. Guider R, Gandolfi D, Chalyan T, Pasquardini L, Samusenko A, Pucker G, Pederzolli C, Pavesi L: Design and Optimization of SiON Ring Resonator-Based Biosensors for Aflatoxin M1 Detection [Internet]. Sensors 2015, 15:17300-17312.

38. Ghali H, Chibli H, Nadeau JL, Bianucci P, Peter YA: Real-time detection of Staphylococcus aureus using Whispering Gallery Mode optical microdisks. Biosensors 2016, 6:20.

39. Ramachandran A, Wang S, Clarke J, Ja SJ, Goad D, Wald L, Flood EM, Knobbe E, Hryniewicz J V., Chu ST, et al.: A universal biosensing platform based on optical microring resonators. Biosens. Bioelectron. 2008, 23:939-944.

40. McClellan MS, Domier LL, Bailey RC: Label-free virus detection using silicon photonic microring resonators. Biosens. Bioelectron. 2012, 31:388-392.

- - This paper represents one of the few whispering gallery modes biosensors in environmental monitoring that detects the target analyte in real samples. The developed immunosensor can specifically detect intact plant viruses in both buffer and 
complex leaf extracts samples.

41. Zhu H, White IM, Suter JD, Zourob M, Fan X: Opto-fluidic micro-ring resonator for sensitive label-free viral detection [Internet]. Analyst 2008, 133:356-360.

42. Lifson MA, Miller BL: Photonic Crystals as Robust Label-Free Biosensors [Internet]. In Photonic Materials for Sensing, Biosensing and Display Devices. . 2016:189-207.

43. Pineda MF, Chan LL-Y, Kuhlenschmidt T, Choi CJ, Kuhlenschmidt M, Cunningham BT: Rapid Specific and Label-Free Detection of Porcine Rotavirus Using Photonic Crystal Biosensors [Internet]. IEEE Sens. J. 2009, 9:470-477.

44. Takahashi D, Hachuda S, Watanabe T, Nishijima Y, Baba T: Detection of endotoxin using a photonic crystal nanolaser [Internet]. Appl. Phys. Lett. 2015, 106:131112.

45. Mayer KM, Hafner JH: Localized surface plasmon resonance sensors [Internet]. Chem. Rev. 2011, 111:3828-3857.

- This review represents a comprehensive overview of the physics, applications based on biological or chemical sensors and technological advances in localized surface plasmon resonance sensors.

46. Estevez MC, Otte MA, Sepulveda B, Lechuga LM: Trends and challenges of refractometric nanoplasmonic biosensors: A review. Anal. Chim. Acta 2014, 806:5573.

47. Cennamo N, Donà A, Pallavicini P, D’Agostino G, Dacarro G, Zeni L, Pesavento M: Sensitive detection of 2,4,6-trinitrotoluene by tridimensional monitoring of molecularly imprinted polymer with optical fiber and five-branched gold nanostars. Sensors Actuators, B Chem. 2015, 208:291-298.

48. Kawaguchi T, Shankaran DR, Kim SJ, Matsumoto K, Toko K, Miura N: Surface plasmon resonance immunosensor using Au nanoparticle for detection of TNT. Sensors Actuators, B Chem. 2008, 133:467-472.

49. Shrivastav AM, Mishra SK, Gupta BD: Localized and propagating surface plasmon resonance based fiber optic sensor for the detection of tetracycline using molecular imprinting [Internet]. Mater. Res. Express 2015, 2:35007.

50. Jakab A, Rosman C, Khalavka Y, Becker J, Trügler A, Hohenester U, Sönnichsen C: Highly Sensitive Plasmonic Silver Nanorods [Internet]. ACS Nano 2011, 5:6880-6885.

51. Kreuzer MP, Quidant R, Salvador JP, Marco MP, Badenes G: Colloidal-based localized surface plasmon resonance (LSPR) biosensor for the quantitative determination of stanozolol [Internet]. Anal. Bioanal. Chem. 2008, 391:1813-1820.

52. Deshmukh NIK, Barker J, Petroczi A, Naughton D: Detection of stanozolol in environmental waters using liquid chromatography tandem mass spectrometry [Internet]. Chem. Cent. J. 2011, 5:63.

53. Kovács R, Csenki Z, Bakos K, Urbányi B, Horváth Á, Garaj-Vrhovac V, Gajski G, Gerić M, Negreira $N$, López de Alda $M$, et al.: Assessment of toxicity and genotoxicity of low doses of 5-fluorouracil in zebrafish (Danio rerio) two-generation study. Water Res. 2015, 77:201-212. 
54. Hiep HM, Yoshikawa H, Tamiya E: Interference localized surface plasmon resonance nanosensor tailored for the detection of specific biomolecular interactions [Internet]. Anal. Chem. 2010, 82:1221-1227.

55. Lin TJ, Huang KT, Liu CY: Determination of organophosphorous pesticides by a novel biosensor based on localized surface plasmon resonance. Biosens. Bioelectron. 2006, 22:513-518.

56. Yang $\mathrm{S}, \mathrm{Wu} \mathrm{T}$, Zhao X, Li X, Tan W: The optical property of core-shell nanosensors and detection of atrazine based on localized surface plasmon resonance (LSPR) sensing [Internet]. Sensors 2014, 14:13273-13284.

57. Yanik AA, Huang M, Kamohara O, Artar A, Geisbert TW, Connor JH, Altug H: An optofluidic nanoplasmonic biosensor for direct detection of live viruses from biological media [Internet]. Nano Lett. 2010, 10:4962-4969.

58. Park TJ, Lee SJ, Kim DK, Heo NS, Park JY, Lee SY: Development of label-free optical diagnosis for sensitive detection of influenza virus with genetically engineered fusion protein. Talanta 2012, 89:246-252.

59. Camara AR, Gouvêa PM, Dias ACM, Braga AM, Dutra RF, de Araujo RE, Carvalho IC: Dengue immunoassay with an LSPR fiber optic sensor [Internet]. Opt. Express 2013, 21:27023-27031.

60. Lin HY, Huang CH, Lu SH, Kuo IT, Chau LK: Direct detection of orchid viruses using nanorod-based fiber optic particle plasmon resonance immunosensor. Biosens. Bioelectron. 2014, 51:371-378.

61. Chen S, Svedendahl M, Käll M, Gunnarsson L, Dmitriev A: Ultrahigh sensitivity made simple: nanoplasmonic label-free biosensing with an extremely low limit-of-detection for bacterial and cancer diagnostics. [Internet]. Nanotechnology 2009, 20:434015.

62. Zhu S, Du C, Fu Y: Localized surface plasmon resonance-based hybrid Au-Ag nanoparticles for detection of Staphylococcus aureus enterotoxin B. Opt. Mater. (Amst). 2009, 31:1608-1613.

63. Kim DK, Yoo SM, Park TJ, Yoshikawa H, Tamiya E, Park JY, Lee SY: Plasmonic properties of the multispot copper-capped nanoparticle array chip and its application to optical biosensors for pathogen detection of multiplex DNAs [Internet]. Anal. Chem. 2011, 83:6215-6222.

- This article reports a localized surface plasmon resonance biosensor synthesizing silica/Cu (core/shell) Nanoparticle arrays on an Au film. This chip allows multiplexing detection of different types of pathogenic bacteria DNA even in complex biological matrices with a limit of detection of few $\mathrm{fM}$. 